\title{
ANALYSIS OF TANNIN IN SAPODILLA FRUIT (Manilkara zapota (L) VAN ROYEN)
}

\author{
Baharuddin Hamzah $^{1}$, Sitti Rahmawati ${ }^{1, *}$, Wayan Samuel Suwena ${ }^{1}$, \\ Muhammad Fakhrul Hardani ${ }^{2}$ and Ririen Hardani ${ }^{2}$ \\ ${ }^{1}$ Departement of Mathematic's and Natural Sciences Education, Faculty of Teacher \\ Training and Education, Tadulako University, Jl. Soekarno Hatta Km 9 Palu 94118, \\ Central Sulawesi, Indonesia \\ ${ }^{2}$ Departement of Pharmacy, Faculty of Mathematic's and Natural Sciences, \\ Tadulako University, Jl. Soekarno Hatta Km 9 Palu 94118, Central Sulawesi, Indonesia \\ *E-mail: sittirahmawati.q3a@gmail.com
}

\begin{abstract}
Sapodilla fruit (Manilkara zapota (L) Van Royen) contains chemical compounds including flavonoids, saponins and tannins. This study aims to determine the types and levels of tannins in sapodilla fruit. Sapodilla fruit was extracted using the maceration method. Sapodilla fruit extract (Manilkara zapota (L) Van Royen) was then tested qualitatively using the following tests: 1) $\mathrm{FeCl}_{3}$ 2) potassium fericyanide and 3) gelatin. The test results showed that sapodilla fruit was positive for tannin. The type of tannin contained in sapodilla fruit is a type of condensed tannin. The quantitative test was performed using the permanganometric method and obtained an average tannin content of $0.84 \%$ with a standard deviation and a coefficient of variation of 0.0710 and $8.45 \%$, respectively.

Keywords: Sapodilla Fruit (Manilkara zapota (L) Van Royen), Maceration, Analysis, Tannin.
\end{abstract}

(C) RASĀYAN. All rights reserved

\section{INTRODUCTION}

Sapodilla fruit (Manilkara zapota (L) van royen) is a tropical fruit originating from America, precisely in Mexico to Guatemala, Salvador, and North Honduras. It is also called neesbery or sapodilla. Sapodilla fruit has soft fruit flesh, but there is a taste texture like sand because sapodilla fruit contains stone cells (sclereida). Sapodilla fruit has properties as a medicine for diarrhea and dysentery. In addition, sapodilla can also be used as an ingredient in processed foods, such as jam, syrup, or fermented into wine or vinegar. ${ }^{1}$

Sapodilla plants contain chemical compounds including flavonoids, saponins and tannins. The three compounds have antibacterial properties. In young sapodilla fruit, the tannin content is higher than the old sapodilla fruit. Antibacterial power that is high in sapodilla due to the high content of tannins so that the sapodilla taste becomes bitter and bitter. ${ }^{2}$

Tannin is defined as phenol polyhydric which is complex with molecular size and shape that allows it to dissolve in water, glycerol, alcohol, and hydroxy alcohol. Tannin, also called tanic acid, $\mathrm{C}_{14} \mathrm{H}_{10} \mathrm{O}_{9}$, is a group of vegetable compounds that are acidic, aromatic, and give a feeling of roughness. Tannin is an active compound of secondary metabolites that is known to have several properties including antidiarrhea, anti-bacterial and antioxidant. ${ }^{3}$

Tanin generally consists of two types, namely condensed tannins and hydrolyzed tannins. These two types of tannins are found in plants, but the most dominant ones in plants are condensed tannins. Identification of tannin can be done by using a solution of $\mathrm{FeCl}_{3}$, gelatin, potassium ferricyanide and ammonia. For quantitative testing of tannins using the permanganometry method. ${ }^{4}$

The desired compound in a plant can be obtained by the extraction process. Extraction is the process of withdrawing metabolites from plants using appropriate solvents. Extracting tannin from Phyllanthus niruri Linn, using various organic solvents (petroleum ether, dikhoromethane, chloroform, methanol, ethanol

Rasayan J. Chem., 13(4), 2243-2248(2020)

http://dx.doi.org/10.31788/ RJC.2020.1345753

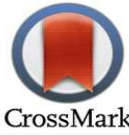


RASĀYAN J. Chem.

Vol. 13 | No. 4 |2243-2248| October - December | 2020

and acetone). ${ }^{5}$ Extracting tannins from avocado (Persea americana Mill) seeds with 95\% ethanol. ${ }^{6}$ Extracting tannins from betel nut (Areca catechu. L) with water and ethanol. ${ }^{7}$ Extracting tannins in tea bags with $70 \%$ ethanol using maceration method. ${ }^{8}$ The use of solvents for extraction is of course adapted to the nature of the content of these plant compounds, generally organic solvents are used for plants containing lipophilic compounds. ${ }^{9}$

The levels of tannins in each plant have different contents in a region, this is caused by the condition of climate, and environmental factors where it grows. This article is intended to analyze tannin levels in sapodilla fruit (Manilkara zapota (L) van royen) which grows in the area of Central Sulawesi.

\section{Sample Preparation}

\section{EXPERIMENTAL}

Choosing sapodilla fruit whose size is not too large, if the outer part of the sapodilla fruit is rubbed it will look green on the inner skin which indicates the sapodilla fruit is still young and there is still much sap. Then wash with water until clean, then dry (aerated at room temperature). Next, cut into small sapodilla fruit with a knife and dioven at a temperature of $45^{\circ} \mathrm{C}$ to dry and mashed with a blender.

Extraction of samples in this study using maceration method. Young sapodilla fruit powder weighed 50 grams, put into maceration container, then added $70 \%$ ethanol $150 \mathrm{~mL}$ until all samples were submerged by solvent, then shaker for 2 hours then covered with aluminum foil, then left for 12 hours. The maceration obtained is filtered with Whatman no.1 paper obtained by filtration and residue. On the dregs, maceration is repeated (repeated 1 time). The obtained filtrate is collected. Then concentrated using a vacuum rotary evaporator at $45^{\circ} \mathrm{C} .{ }^{10}$

\section{Identification of The Type of Tannin}

Sapodilla fruit extract (Manilkara zapota (L) van royen), then performed a qualitative test using: (1) The extracted filtrate is added with $1 \mathrm{~mL}$ of $\mathrm{FeCl}_{3}$. A positive test for the presence of tannins will give a blueblack precipitate to the hydrolyzed tannin and give a greenish-black precipitate to the condensed tannin. (2) The extract was added with $1 \mathrm{ml}$ of potassium fericyanide and $1 \mathrm{ml}$ of ammonia. A positive test for the presence of tannins will give a dark red color. (3) The extract was added with $1 \mathrm{~mL}$ of $1 \%$ gelatin solution containing $\mathrm{NaCl}$. A positive test for the presence of tannins will result in a sediment ${ }^{11}$. (4) The extract is added with $1 \mathrm{~mL}$ of ammonia solution then exposed to open air. Test positive for the presence of tannins with the appearance of green color.

\section{Determination of Tannin Level by Permanganometry}

\section{Making of Primary Standard Solution of 0.1N Oxalic Acid}

0.67 grams of solid oxalic acid is weighed and then dissolved with enough aquadest in the beaker. Enter into a $100 \mathrm{~mL}$ volumetric flask, then add aquadest to the limit mark on the measuring flask. Then calculate $\mathrm{N}$ oxalic acid. ${ }^{12}$ The formula for calculating $\mathrm{N}$ oxalic acid:

$$
\mathrm{N} \text { Oxalic acid }=\frac{\text { gram }}{\mathrm{Mr}} \times \frac{1000}{\mathrm{p}} \mathrm{x} \text { equivalent }
$$

\section{Standardization of KMnO4 with 0.1N Oxalic Acid}

$10 \mathrm{~mL}$ of $0.1 \mathrm{~N}$ oxalic acid solution was put into $100 \mathrm{~mL}$ Erlenmeyer, $10 \mathrm{~mL}$ of $4 \mathrm{~N} \mathrm{H}_{2} \mathrm{SO}_{4}$ solution was added, heated to $70^{\circ} \mathrm{C}$ then titrated with $\mathrm{KMnO}_{4} 0.1 \mathrm{~N}$. The titration is stopped if there has been a change in color or has reached the endpoint of titration ${ }^{12}$. Repeated 5 times. The results of determining the normality of $\mathrm{KMnO}_{4}$ are determined by the formula ${ }^{12}$ :

\section{Determination of Total Tannin Level}

$$
\mathrm{N} \mathrm{KMnO}_{4}=\frac{\text { Oxalic acid volume } x \mathrm{~N} \text { Oxalic acid }}{\mathrm{KMnO}_{4} \text { volume }}
$$

2 grams of dried sapodilla powder which has been mashed is put into a beaker. Then added $50 \mathrm{~mL}$ of aquadest, heated over the water bath until boiling for 30 minutes while stirring. Let stand for a few minutes, deposited, then filtered using filter paper and obtained the filtrate. The pulp is filtered again with hot aquadest. Screening is done several times until the residue does not show a change in color to black blue when reacted with $\mathrm{FeCl}_{3}$. 
RASĀYAN J. Chem.

Vol. 13 | No. 4 |2243-2248| October - December | 2020

The filtrate obtained was taken $25 \mathrm{ml}$ and then entered into a $250 \mathrm{~mL}$ volumetric flask and added aquadest to the measuring flask limit. $2.5 \mathrm{~mL}$ of solution was put into $250 \mathrm{~mL}$ erlenmeyer, $75 \mathrm{~mL}$ of aquadest was added and $2.5 \mathrm{~mL}$ of the indigo carmine indicator. Then, titrated with $\mathrm{KMnO} 4$ until the color changes from dark blue to golden yellow. Recorded the volume of $\mathrm{KMnO}_{4}$ used. Repeat 5 times. ${ }^{13,14}$ The results of determining the total tannin can be determined by the formula: ${ }^{13,14}$

$$
\% \text { Tannin }=\frac{10(\mathrm{~A}-\mathrm{B}) \times \mathrm{N} \mathrm{x} \mathrm{0,0415}}{\text { Sample }(\mathrm{g})} \times 100 \%
$$

Where $\mathrm{A}$ is the volume of tannin titration $(\mathrm{mL}) ; \mathrm{B}$ is the volume of blank titration $(\mathrm{mL}) ; \mathrm{N}$ is the normality of standard $\mathrm{KMnO}_{4}(\mathrm{~N})$; and 10 is a dilution factor. $1 \mathrm{ml}$ of $\mathrm{KMnO} 40.1 \mathrm{~N}$ equals 0.0415 grams of tannin.

\section{Sapodilla Extract}

\section{RESULTS AND DISCUSSION}

Tannin is an organic substance that is very complex and consists of phenolic compounds that are found in various plants. Generally, tannins are distributed in almost all parts of the plant, such as the bark, stems, leaves and fruit. ${ }^{15}$ Tannin is an active secondary metabolite compound that is known to have several properties including anti-diarrhea, anti-bacterial, and antioxidant properties. The sapodilla fruit extraction was carried out by using the kinetic maceration method. This method is a cold maceration that does not go through a heating process to obtain the extract to avoid damage to the compounds contained in sapodilla fruit at high temperatures. ${ }^{16}$ The extract of sapodilla fruit (Manilkara zapota (L) Van Royen) obtained $29.3 \mathrm{~mL}$ of dark brown sapodilla fruit extract.

\section{Qualitative Analysis of Tannin}

The test to determine the presence of tannins in sapodilla fruit, used the addition of $\mathrm{FeCl}_{3}$ to determine whether the sample contains phenol groups. The presence of phenol groups is indicated by a blackishgreen or dark blue color after adding $\mathrm{FeCl}_{3}$, so that if the $\mathrm{FeCl}_{3}$ test gives positive results, the sample may contain phenolic compounds and one of them is tannins because tannins are polyphenolic compounds. ${ }^{17}$

The results showed that the addition of $\mathrm{FeCl}_{3}$ solution to sapodilla fruit extract resulted in a black-green color change. This shows the presence of a phenol group in the tannin that binds to $\mathrm{FeCl}_{3}$ to form a blackgreen complex because tannins form complex compounds with $\mathrm{Fe}^{3+}$ ions (Fig.-1). These results indicated that sapodilla fruit was positive for tannin.

The addition of potassium ferricide and ammonia produces a dark red color which indicates the presence of tannins in sapodilla fruit. The reaction of tannins with potassium ferricide and ammonia can be seen in the following reaction:

$$
\mathrm{C}_{7} \mathrm{H}_{52} \mathrm{O}_{46}+\mathrm{K}_{4} \mathrm{Fe}(\mathrm{CN})_{6} \rightarrow \mathrm{KC}_{76} \mathrm{H}_{51} \mathrm{O}_{46}+\mathrm{H}_{4} \mathrm{Fe}(\mathrm{CN})_{6}
$$

Ammonia test ethanol extract of $70 \%$ sapodilla fruit produces a green color after exposure to open air, with these results, the sapodilla fruit extract contains positive tannins. The detailed results of the tannin identification test can be seen in Table-1.

Table-1: Identification of Tannin

\begin{tabular}{c|c|c}
\hline Reagent & Result & Concl. \\
\hline $\mathrm{FeCl}_{3}$ & Greenish Black & + \\
\hline Gelatin Salt Solution & Precipitation & + \\
\hline $\mathrm{K}_{3} \mathrm{Fe}(\mathrm{CN})_{6}+$ Ammonia & Dark Red & + \\
\hline Ammonia Test & Green & + \\
\hline
\end{tabular}

Tannins are divided into two groups, namely easily hydrolyzed tannins and condensed tannins. ${ }^{18}$ Based on the data in Table-1, the formation of a greenish black color and the presence of sediment (positive test for condensed tannins) indicates the type of tannin contained in sapodilla fruit. The results obtained indicate that the type of tannin contained in sapodilla fruit (Manilkara zapota (L) van royen) is a type of condensed tannin. Condensed tannins are polymers of flavonoid compounds with carbon-carbon bonds in the form of cathecin and gallocathecin. ${ }^{19}$

The next test used a gelatin solution (Table-1). This test is a preliminary test to strengthen the suspicion of tannin compounds in sapodilla fruit extract. All tannins create a little or a lot of deposits when added with gelatin. The addition of a salt solution to which gelatin is added forms a yellowish white precipitate. The 
RASĀYAN J. Chem.

Vol. 13 | No. 4 |2243-2248| October - December | 2020

presence of a yellowish-white precipitate indicates that tannins coagulate proteins from gelatin, because tannins can react with proteins to form copolymers that are insoluble in water. ${ }^{17}$ The reaction between tannins and gelatin can be seen in Fig.-2.

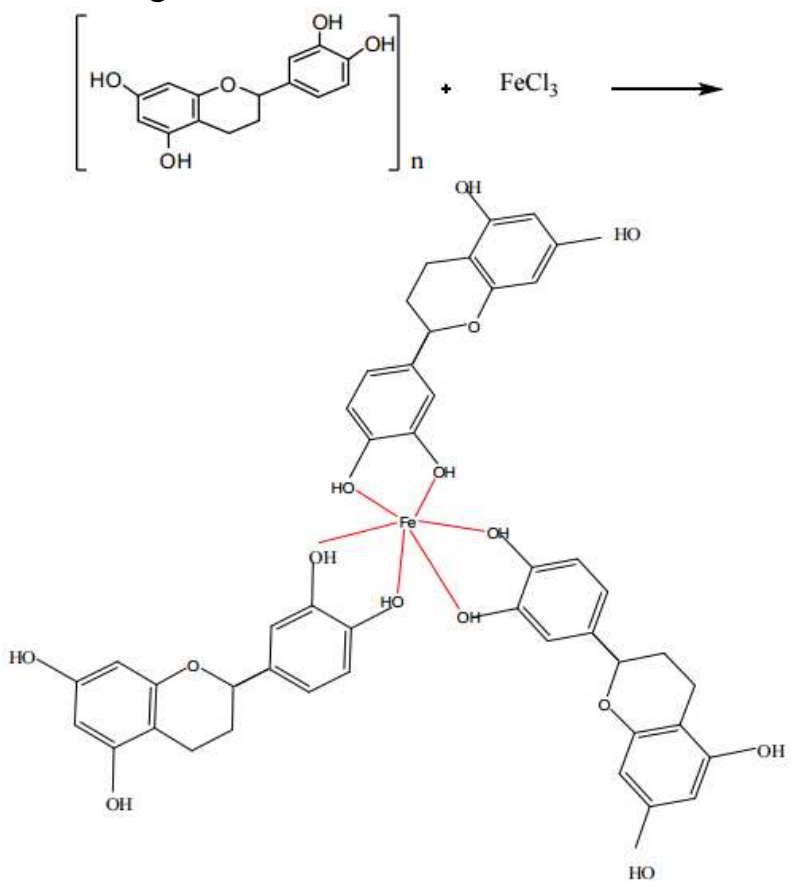

Fig.-1: Reaction between Tannin and $\mathrm{FeCl}_{3}{ }^{17}$
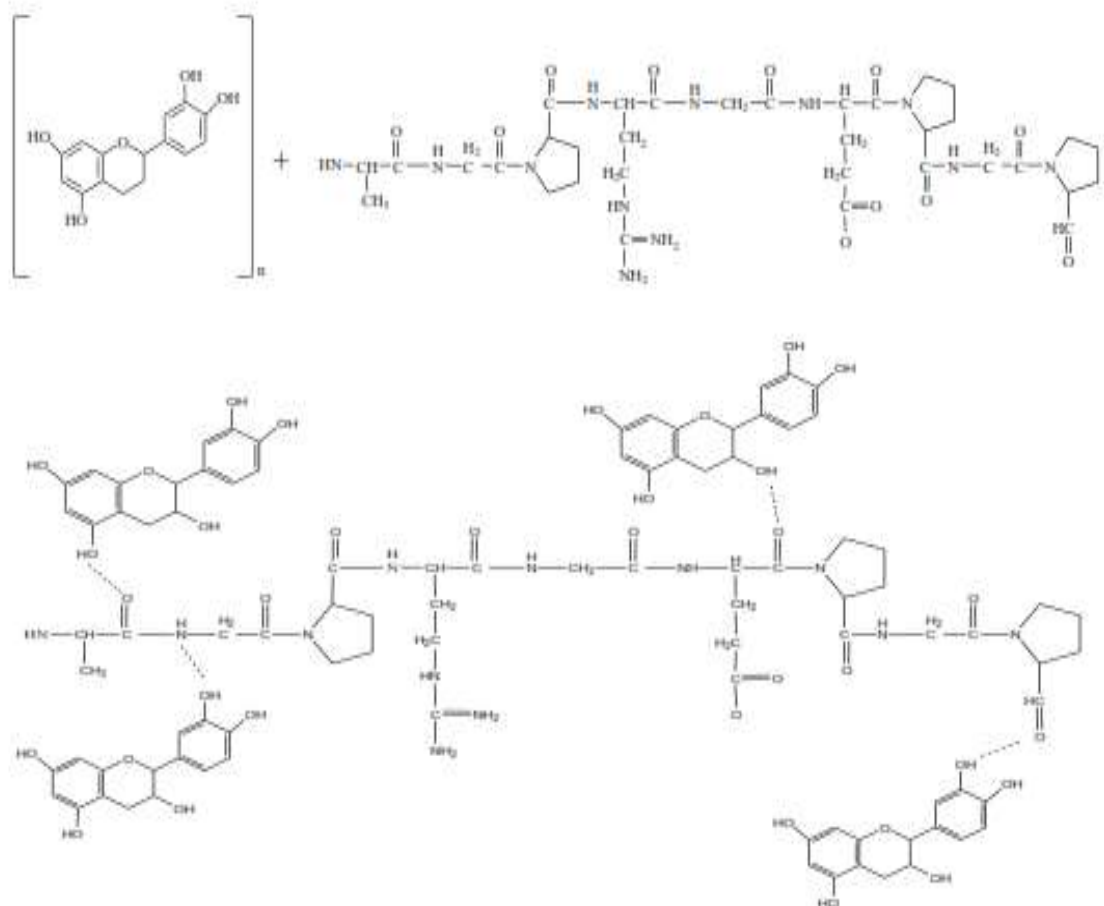

Fig.-2: Reaction between Tannin and Gelatin ${ }^{20}$

Quantitative analysis to determine the total tannin content of sapodilla fruit peel (Manilkara zapota (L) van royen) was carried out by permanganometric titration method. This method uses the principle of the redox reaction (reduction-oxidation), potassium permanganate as the oxidizing agent and the reducing 
RASĀYAN J. Chem.

Vol. 13 | No. 4 |2243-2248| October - December | 2020

agent is oxalic acid (primary standard solution). The indicator used in this titration is indigo carmine (TAT) which is shown by the color of the solution changing to golden yellow, in determining the levels of tannins. ${ }^{21}$

Blank titration was also carried out which aims to determine the volume of $\mathrm{KMnO}_{4}$ which reacts with indigo carmine. The volume of the blank titration is used as a reduction factor in the titration volume of the sample. From the results of the titration which was carried out five times, the percent of the total tannin content was determined. The results of determining the total tannin content in sapodilla fruit can be seen in Table-2.

Table-2: Determination of Tannin in Sapodilla Fruit

\begin{tabular}{c|c|c|c}
\hline Powder & \multicolumn{2}{|c|}{ Titran Vol. (ml) } & Tannin Level \\
Weight (g) & Sample (A) & Blank (B) \\
\cline { 2 - 3 } 4.02 & 2.1 & 1.4 & 0.74 \\
4.03 & 2.1 & 1.3 & 0.84 \\
4.01 & 2.2 & 1.4 & 0.85 \\
4.02 & 2.2 & 1.3 & 0.95 \\
4.01 & 2.2 & 1.4 & 0.85 \\
\hline \multicolumn{2}{c}{ Average Tannin Level (\%) } & 0.84 \\
\hline \multicolumn{3}{c}{ SD } & 0.071 \\
\hline \multicolumn{3}{c}{ KV(\%) } \\
\hline
\end{tabular}

The results of the quantitative determination of the tannin content in sapodilla fruit (Manilkara zapota (L) van royen) by permanganometry showed that the average tannin content was $0.84 \%$. The sample weight is obtained from reducing the sample weight before extraction by the weight of the sample after extraction.

The results of the determination of the tannin content in sapodilla fruit, when compared with several previous studies on different types of fruit, obtained different results (smaller). Determination of total tannin content from old coconut fibers obtained a tannin content of $4.28 \%$ and young coconut fibers obtained a tannin content of $5.62 \%{ }^{12}$, determination of tannin content from young flower fruit obtained a tannin content of $7.98 \% .{ }^{22}$ Determination of tannin content from ripe banana fruit peels obtained a tannin content of $0.8 \%{ }^{13}$, lower than the tannin content in sapodilla fruit.

The standard deviation (standard deviation) shows the degree or degree of variation in the data set from the mean. This standard deviation is used to show how different the existing data is compared to the average data. The coefficient of variance (variability) is a comparison between the standard deviation and the average value and is expressed as a percentage. The coefficient of variance shows the proportion of the standard deviation to the mean. The results of the calculation of Standard Deviation (SD) and the Coefficient of Variance (KV) on sapodilla fruit (Table-2) are 0.0710 and $8.45 \%$. The accuracy in this analysis can be said to be good, because the coefficient of variance obtained is small. The small coefficient of variance also shows good homogeneity, because the results obtained are not too far away. ${ }^{23}$ This value indicates that this method is suitable for use in the analysis of tannin determination.

\section{CONCLUSION}

Based on the results of the research that has been done, it can be concluded that the sapodilla fruit (Manilkara zapota (L) van royen) contains tannin which is classified as a type of condensed tannin. In the determination of tannin content using the permanganometry method, the average tannin content obtained in sapodilla fruit (Manilkara zapota $(\mathrm{L})$ van royen) was $0.84 \%$.

\section{ACKNOWLEDGMENT}

The authors would like to thank the Head and Staff of Chemistry Education Laboratory at the Faculty of Teacher Training and Education Tadulako University for their kind help in this work.

\section{REFERENCES}

1. J.H. Crane, C.F. Balerdi, and I. Maguire, The Institute of Food and Agricultural Sciences (IFAS), Florida, p.1,7 (2019)

2. P. Saranraj, and S. Sivasakthi, Global Journal of Pharmacology, 8(3), 316(2014), DOI: 
RASĀYAN J. Chem.

Vol. 13 | No. 4 |2243-2248| October - December | 2020

10.5829/idosi.gjp.2014.8.3.83194

3. Y. Desmiaty, H. Ratih, M.A. Dewi and R. Agustin, Ortocarpus, 8, 106(2008)

4. T. Desinta, Calypatra: Jurnal Ilmiah Mahasiswa Universitas Surabaya, 4(1), 1(2014)

5. M. Markom, M. Hasan, W.R.W. Daud, H. Singh and J.M. Jahim, Separation and Purification Technology, 52(3), 487(2007), DOI:10.1016/j.seppur.2006.06.003

6. L.P. Malangngi, M.S. Sangi and J.E.P. Jessy, Jurnal MIPA, 1(1), 5(2012), DOI: $10.35799 / \mathrm{jm} \cdot 1.1 .2012 .423$

7. T. Sulastri, Jurnal Chemica, 10(1), 59(2009), DOI:10.35580/chemica.v10i1.401

8. A. Fajrina, J. Jubahar and S . Sabirin, Jurnal Farmasi Higea, 8(2), 133(2016)

9. F. Khachik and A.N. Chang, The Journal of Organic Chemistry, 74(10), 3875(2009), DOI: 10.1021/jo900432r

10. D. H. S. Palupi, D. S. Retnoningrum, M. I. Iwo, and A. A. Soemardji, Rasayan Journal of Chemistry, 13(1), 636(2020), DOI:10.31788/RJC.2020.1315519

11. Cut Nuraskin, Marlina, R. Idroes, C. Soraya and Djufri, Rasayan Journal of Chemistry, 13(1), 18(2020), DOI:10.31788/RJC.2020.1315434

12. F.R. Lisan and S. Palupi, Calypatra: Jurnal Ilmiah Mahasiswa Universitas Surabaya, 4(1), 1(2015)

13. E. Ryanata, S. Palupi, and A. Azminah, Calyptra : Jurnal Ilmiah Mahasiswa Universitas Surabaya, 4(1), 1(2015)

14. A. R. Prihadi, A. Maimulyanti, B. Mellisani and Nurhasanah, Rasayan Journal of Chemistry, 13(2), 955(2020), DOI: 10.31788/RJC.2020.1325613

15. S. Dur, Jurnal Al-Irsyad, 3, 106(2013)

16. A. Dewi, I.U. Pri and A.D. Binar, Pharmacy, 7(2), 1(2010), DOI:10.30595/pji.v7i1.552

17. J. B. Harborne, Metode fitokimia: Penuntun cara Modern menganalisis tumbuhan, Bandung, Institut Teknologi Bandung(1987)

18. A.E. Hagerman, C.T. Robbins, Y. Weerasuriya, T.C. Wilson and C.M. Arthur, Journal of Range Management, 45(1), 57(1992)

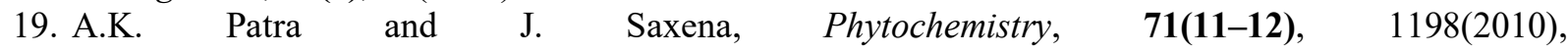
DOI: $10.1016 /$ j.phytochem.2010.05.010

20. R.H.M.J. Leemens and S.N. Wulijarni, Journal of the Society of Dyers and Colourists, 107, 414 (1991), DOI:10.1111/j.1478-4408.1991.tb01289.x

21. A.L. Underwood and R.A. Day, Analisa Kimia Kuatitatif. (L. Spyan, Ed.), Erlangga, Jakarta(2006).

22. F.R. Amelia, Calyptra : Jurnal Ilmiah Mahasiswa Universitas Surabaya, 44(22), 1(2015)

23. I.G. Gandjar and A. Rohman, Kimia Farmasi Analisis, Pustaka Pelajar, Yogyakarta(2007).

[RJC-5753/2020] 